\title{
The Role of The Employee Succession System in Developing Human Resources
}

\author{
Mohammed Khalaf Hasan Al-Muttairi, Prof. Dr. Nadhum Jawad Abid Al-Zeidi
}

DOI: $10.37648 /$ ijrssh.v10i04.021

Received:10 $0^{\text {th }}$ October, 2020; Accepted:04 ${ }^{\text {th }}$ November, 2020; Published: $07^{\text {th }}$ November, 2020

\begin{abstract}
The main objective of this research is to identify the importance of the role of succession planning in developing human capital in organizations in light of the accelerating and dynamic events and changes in the work environment. The research problem indicated the danger of employees retiring or leaving their positions for any reason and the extent of its impact on the organization in creating Gaps in leadership and problems in managing the talent injection, because there will be a shortage of talent, which in turn will affect the general performance of the work in the researched institute, so the importance of research appears in trying to present a set of solutions through which some of the problems facing the organization under consideration are addressed to the extent of The matter related to the researched variables, where the researcher relied on the questionnaire as a main tool for the purpose of collecting research data and concluded the importance of the role of succession planning in developing human capital and enhancing the knowledge, capabilities and capabilities of employees and their industry as prepared alternatives.
\end{abstract}

\section{INTRODUCTION}

Effective organizations do not passively anticipate the future, but rather innovate it by investing their time, ideas and planning in order to ensure the continuity of their leadership talent, and this process is known as succession planning, as it is more than just replacing jobs that will become vacant, but rather an ongoing process of identifying talent Evaluating and developing them to ensure the continuity of leadership, management and supervision throughout the organization, the interest of thinkers in leadership and human capital coincided with the interest in the topic of human resource development and interest by economic thinkers such as (Adam Smith and Parker) and trying to show the active role that the theory of human capital occupied. In organizations and how to develop it, and its importance that is not less than the physical assets of the organization if not greater than it, hence the idea of the research to shed light on the role of succession planning in the development of human capital, in an attempt to show the relationship between the stages of succession planning and the extent of its impact on the dimensions of the development of the head Human money.

\section{RESEARCH PROBLEM}

The following questions can be asked to express the content of the research problem:

1- Is there a significant relationship and influence between succession planning and human capital development?

2- Is there an impact of succession planning on human capital development? 


\section{RESEARCH ASSUMES}

The first main hypothesis: There is a significant correlation relationship between the stages of succession planning with the dimensions of human capital development combined.

The second main hypothesis: There is a significant influence of the stages of succession planning on the combined dimensions of human capital development.

\section{THE RESEARCH SAMPLE}

The research community was chosen at the Baghdad Oil Training Institute, one of the formations affiliated with the Iraqi Ministry of Oil, where the size of the research community reached (561) employees from among the workers. The research sample consisted of all the administrative positions in the researched institute represented by (director of the institute and his assistants, department directors and their agents, People officials or their representatives) and the group of the exclusive intentional research sample amounted to (66) people.

\section{PREVIOUS STUDIES}

This research aims to present the most important previous studies that try to draw the features of this research, and to benefit from them in formulating intellectual propositions, models or strategies, measures, statistical tools, and quantitative analysis, which dealt with one of the research variables (succession planning, human capital) and the relationship between them .

-Study (Umans \& Est, 2018) The study aimed to find out the extent of the impact of intentions and planning for work on succession in the success of the institution and the sustainability of its survival from one generation to the next.

-Study (Ismail \& abdulah, 2011) The study aimed to identify the various aspects of human capital development that have been emphasized through the academic programs offered by Malaysian universities in order to provide high human capital.

-Study (Al-Abadi and Al-Moamen, 2017) The study aimed to identify the philosophy of strategic planning and the concept of human capital, and to create an applied vision on how to develop it through strategic planning.

- Study (Dawali, 2019) The study aimed to identify the importance of concern for human capital and its role in increasing the effectiveness of employees' job performance.

-Study (Saleh, 2015) The study aimed to prove the importance of succession in building leaders who bear responsibility and make decisions in the future.

-Study (Muhammad, 2018) The study aimed to know the extent of the impact of succession planning on human resource development, the existence of an impact of human resource development on achieving the sustainability of economic institutions, the existence of an impact of succession planning on the sustainability of economic institutions, and identifying the concept and objectives of corporate sustainability Economic.

\section{THEORETICAL FRAMEWORK}

\section{SUCCESSION PLANNING}

A person who does not worry about the future will soon feel anxious about (the present) (An ancient Chinese proverb). From its origins to the present time period, human groups and societies have attempted to develop structures and systems to aid in survival, harmonious life and stability (Rothwell, 2010: 12). One of the survival strategies that human societies use all the time is locational continuity. In addition, community leaders throughout human history have placed value on human capital (Yadav \& Shankar, 2017: 407). Significant research, studies, and strategies related to succession planning established throughout the twentieth century and continued into the twenty-first century (Swanson, 2018: 37). While succession planning has varied across societies and history, the primary purpose of survival is through continuity and preparing caliphs remains (Yadav \& Shankar, 2017: 407). Succession planning is a targeted risk management strategy to maintain the continuity of operations because when employees leave the organization for whatever reason, They take with them tacit knowledge of how to get things done (Mejorando Group, 2020). So the organizations face the task of replacing them. If the organization does not have a succession plan in place, leaving may cause 
waves of disruption to spread throughout the organization. If the organization has taken the time to put in place an accurate succession plan, leaving may just be a ripple. It is up to (Dahlke, 2012: 1) . Seniwoliba believes that succession planning is the intentional and methodical effort made by the leadership of organizations to recruit, develop and retain individuals with a set of leadership competencies capable of implementing current and future organizational goals (Seniwoliba, 2015: 2).

And that succession planning is a tool used to facilitate the gradual development of successors to take up positions, and it allows older employees to share their knowledge and experiences with young employees in stages (2013: 21, Byrne) and includes the following six stages : -

1- Defining the targeted jobs

2- Determining the competencies and skills required for success and distinction in these jobs

3- Identifying the target human resources

4- Evaluating and developing the targeted human resources

5- Implementation of succession strategies

6- Evaluation of succession effectiveness

\section{HUMAN CAPITAL DEVELOPMENT}

In the past twenty years, the concept of human capital has evolved greatly, and the current concepts of human capital encompass a wide range of human features related to job performance and productivity, ranging from personality traits, work attitudes and values (Lenihana, et al., 2019: 2). The organization's focus on developing human capital is mainly due to its characteristics, the most important of which are (its increased use and length of its life cycle) compared to the life cycle of the product, process, or technology in the organization, as knowledge and experience is transmitted among employees, which provides better opportunities for renewing this knowledge. This is what makes human capital the highest form of the organization's capital and it is the most vital and capable of renewing itself and generating its renewed value, and that risking it is the most threatening to the organization in case of (shortage, leakage, disloyalty) (Najm, 2010: 141). Accordingly, we conclude that for the development of human capital the knowledge, skills and abilities of employees grow through a positive effect on their attitudes and behavior, and here the importance of preserving them and paying attention to them appears, and research on human capital has traditionally focused on education and training, and attention to the elements related to incentives for development is often ignored. Human capital, represented by (job satisfaction, organizational commitment, desire for change in the workplace), which has been proven in economic research to drive innovation and increase production efficiency, and most likely in organizations working to develop their human resource systems should focus on developing these The elements, which appear to be most directly related to understanding employees' desire and motivation to contribute to innovation in work organizations, because well-managed HR systems have a strong influence on employee satisfaction probability, commitment, willingness to make changes, risk tolerance, and additional effort (Lenihana, et al., 2019: 3) Writers and researchers have differing opinions regarding the elements of human capital development due to their different theoretical directions. On the one hand, their scientific and scientific experiences on the one hand, and their practical experiences on the other hand, and based on that, the dimensions most agreed upon by most researchers, which will be dealt with as follows:

1- Knowledge Development

2- Skills Development

3- Experience Development

4- Training Capacity Development

5- Creative Capacity Development 


\section{TEST HYPOTHESES FOR RESEARCH}

1- Test the correlations between succession planning and human capital development, where the most important results came in the table of values of correlations between succession planning and human capital development as follows : -

\begin{tabular}{|c|c|c|c|c|c|c|c|c|c|c|}
\hline \multirow{2}{*}{ S } & \multirow{2}{*}{\multicolumn{2}{|c|}{$\begin{array}{l}\text { Human capital } \\
\text { development }\end{array}$}} & \multicolumn{5}{|c|}{ Human capital development } & \multirow{2}{*}{ 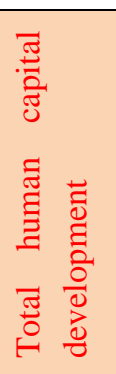 } & \multicolumn{2}{|c|}{$\begin{array}{l}\text { Moral } \\
\text { relationships }\end{array}$} \\
\hline & & & 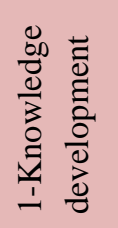 & 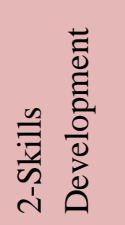 & 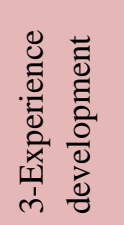 & 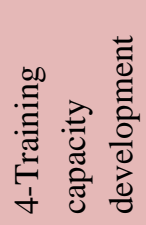 & 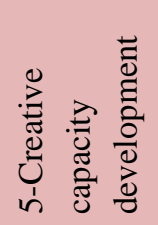 & & 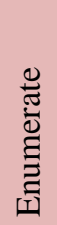 & 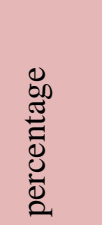 \\
\hline 1 & \multicolumn{2}{|c|}{$\begin{array}{l}\text { Determine target } \\
\text { jobs }\end{array}$} & $0.760^{* *}$ & $0.703^{* *}$ & $0.714^{* *}$ & $0.707^{* *}$ & $0.641^{* *}$ & $0.766^{* * *}$ & 6 & $100 \%$ \\
\hline 2 & \multicolumn{2}{|c|}{$\begin{array}{l}\text { Determine the } \\
\text { competencies and } \\
\text { skills required for } \\
\text { success and } \\
\text { excellence in } \\
\text { these jobs }\end{array}$} & $0.773^{* *}$ & $0.730^{* * *}$ & $0.762^{* *}$ & $0.717^{* *}$ & $\mathbf{0 . 7 0 3}^{* *}$ & $0.802^{* *}$ & 6 & $100 \%$ \\
\hline 3 & \multicolumn{2}{|c|}{$\begin{array}{l}\text { Determine the } \\
\text { target human } \\
\text { resources }\end{array}$} & $0.761^{* *}$ & $0.785^{* *}$ & $0.782^{* *}$ & $0.759^{* *}$ & $0.736^{* *}$ & $0.813^{* *}$ & 6 & $100 \%$ \\
\hline 4 & \multicolumn{2}{|c|}{$\begin{array}{l}\text { Evaluate and } \\
\text { develop targeted } \\
\text { human resources }\end{array}$} & $0.826^{* *}$ & $0.842^{* *}$ & $0.775^{* * *}$ & $0.724^{* *}$ & $0.769^{* *}$ & $0.854^{* *}$ & 6 & $100 \%$ \\
\hline 5 & \multicolumn{2}{|c|}{$\begin{array}{l}\text { Implement } \\
\text { succession } \\
\text { strategy }\end{array}$} & $0.752^{* *}$ & $0.776^{* *}$ & $0.756^{* * *}$ & $0.750^{* *}$ & $0.726^{* *}$ & 0.796 ** & 6 & $100 \%$ \\
\hline 6 & \multicolumn{2}{|c|}{$\begin{array}{l}\text { Evaluation of } \\
\text { succession } \\
\text { effectiveness }\end{array}$} & $0.730^{* *}$ & $0.734^{* * *}$ & $0.740^{* *}$ & $0.782^{* *}$ & $0.650^{* *}$ & $0.775^{* *}$ & 6 & $100 \%$ \\
\hline \multicolumn{3}{|c|}{$\begin{array}{l}\text { Total succession } \\
\text { planning }\end{array}$} & $\mathrm{0.839}^{* *}$ & $\begin{array}{l}0.837 * \\
*\end{array}$ & $\begin{array}{l}0.814 * \\
*\end{array}$ & $0.812^{* *}$ & $0.770^{* *}$ & $0.877^{* *}$ & 6 & $100 \%$ \\
\hline \multirow{2}{*}{\multicolumn{2}{|c|}{$\begin{array}{l}\text { Moral } \\
\text { relationshi } \\
\text { ps }\end{array}$}} & $\begin{array}{l}\text { Enumerat } \\
\mathrm{e}\end{array}$ & 7 & 7 & 7 & 7 & 7 & 7 & 42 & \\
\hline & & $\begin{array}{l}\text { percentag } \\
\mathrm{e}\end{array}$ & $100 \%$ & $100 \%$ & $100 \%$ & $100 \%$ & $100 \%$ & $100 \%$ & & $100 \%$ \\
\hline
\end{tabular}

The results of the relationship between succession planning and the total human capital development are a strong and significant correlation relationship at the level of $(0.01)$ with a correlation coefficient of $(0.877 * *)$. These results outlined above reinforce and provide sufficient support for the purpose of accepting the first main hypothesis.

2- Test the effect between succession planning and human capital development, where the most important results came in the table of the effect of succession planning dimensions on human capital development as follows: - 
(IJRSSH) 2020, Vol. No. 10, Issue No. IV, Oct-Dec

e-ISSN: 2249-4642, p-ISSN: 2454-4671

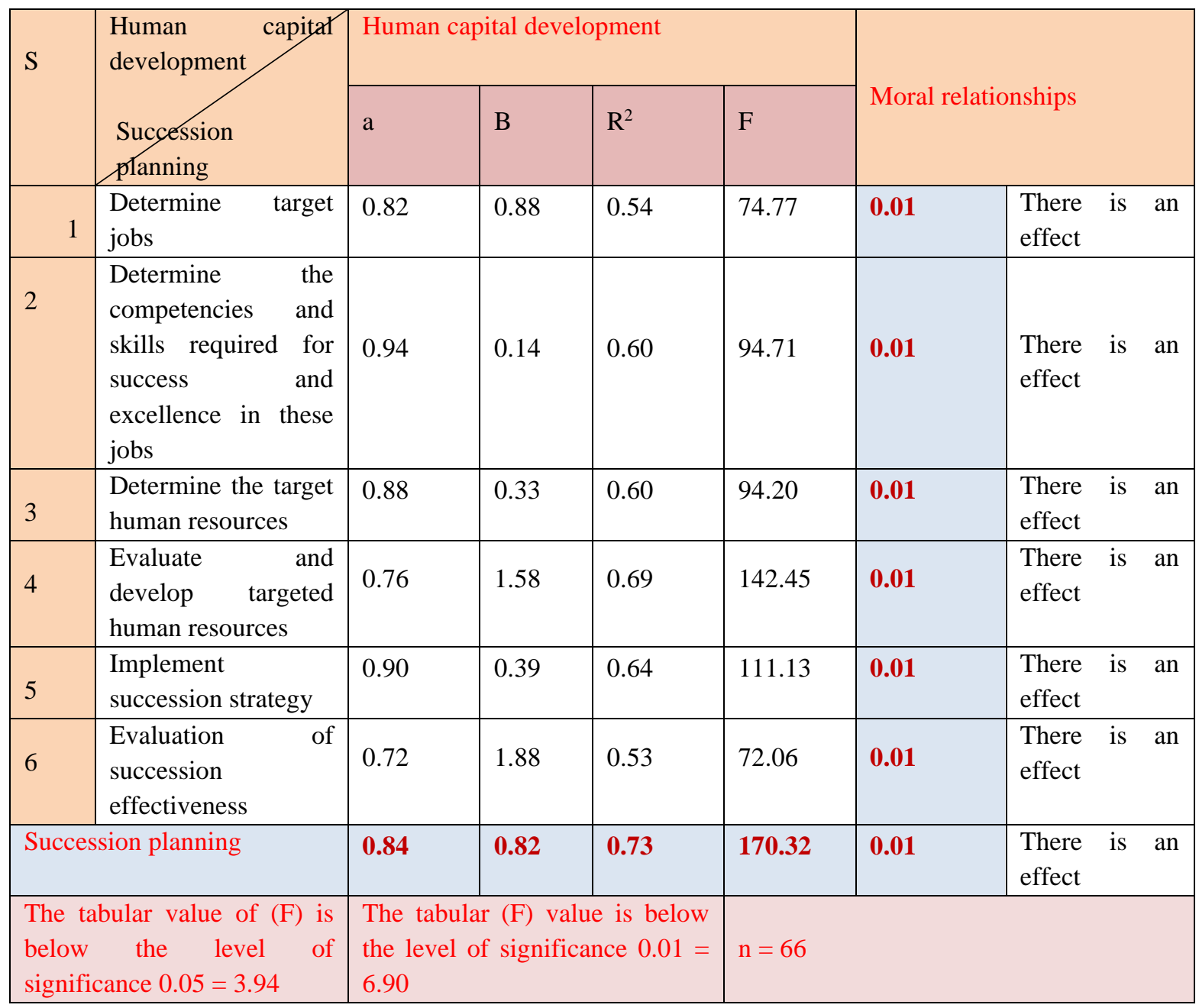

Where the result of the total significant impact relationship of succession planning in the total human capital development showed below the level of (0.01) in terms of the calculated value of (F) of (170.32) which is higher than the tabular value of $(\mathrm{F})$ of $(6.90)$, while the value of (a) constant $=(0.84)$ This indicates that there is a development in human capital of $(84 \%)$, while the value of (B) was (0.82). This means that changing behavior in succession planning by one unit will lead to a change in development opportunities Human capital at (82\%) as the value of (R2) was (0.73), which indicates to us that succession planning is explained by (73\%) of the phenomenon of human capital development.

The results indicated above reinforce and provide sufficient support for the purpose of accepting the second main hypothesis.

\section{CONCLUSIONS}

We review a set of conclusions reached by the researcher based on the results of the analysis of the practical side and what the results showed in the statistical analysis that were discussed in the field side of the research.

1- The interest of the higher management in the researched institute in planning succession and properly activating it in all its stages.

2- The researched institute is developing human capital in a good way, at the level of its five dimensions. 
3- It appears that the higher management in the researched institute has been able, through the practices it follows and implements, to have an effective and strong role in developing human capital, and this indicates the institute's interest in human capital to grow and advance the organizational success ladder.

4- It was found that succession planning in the researched institute was the procedures in it in the field of keeping up with and seizing opportunities for sudden changes through the practices that it follows and implements, which led to the events of changes and influences and in a very high manner in the development of human capital.

5- In light of the research results, we see that succession planning has a major role in developing human capital in organizations.

\section{RESOURCES}

1- Najm, Aboud Najm (2010): The Tangibles Department, Malayas Administration, Al-Yazouri Scientific Publishing and Distribution House, Jordan.

2- Dawali, Nihal Al-Saeed Abdel Aziz (2019): The role of human capital in increasing the effectiveness of job performance, Ain Shams University, Egypt, unpublished master's thesis.

3- Abdul-Karim, Ali Ihsan (2018): Evaluation of variables affecting career succession planning, an exploratory study in the faculties and departments of Tikrit University, College of Administration and Economics, University of Tikrit, Iraq, unpublished master's thesis.

4- Saleh, Mohiuddin Abdullah (2015): The Impact of Succession Planning on Building Future Leaders, Department of Business Administration, Sudan University of Science and Technology, Sudan, unpublished master's thesis.

5- Al-Abadi, Hashem Fawzi, Ihssan Amouri Al-Moamen (2017): Strategic Planning for Health Institutions and Its Role in Developing Human Capital, Al-Ghari Journal for Economic and Administrative Sciences, University of Kufa, Iraq, Volume (14), Edition 2

6- Muhammad, Hoda Salman Mahmoud (2018): The impact of succession planning on the development of human resources for the sustainability of Egyptian economic institutions (a comparative study), Ain Shams University, Egypt, unpublished doctoral thesis.

7- Byrne, Helen ( 2013 ) : Talent Management and Succession Planning, Human Resources Strategies to Avoid a Skills Gap Forming During a Recessional Climate , National College of Ireland, Ireland .

8- Dahlke, Arnie ( 2012 ) : Business Succession Planning FOR Dummies . John Wiley \& Sons, Inc . Canada .

9- Lenihana, Helena \& McGuirkb, Helen \& Murphyc , Kevin R . (2019) ) : Driving innovation : Public policy and human capital , Published by Elsevier B.V. This is an, Research Policy 48, 103791 .

10-Mejorando Group ( 2020 ) : https://gettingbetterallthetime.com/government-succession-planning/ .

11-Rothwell, William. J. ( 2010 ) : Effective Succession Planning : Ensuring Leadership Continuity and Building Talent from Within . 4th ed. New York: American Management Association.

12-Seniwoliba A. J. ( 2015 ) : Succession planning: Preparing the next generation workforce for the University for Development Studies, Research Journal of Educational Studies and Review Vol. 1 (1), pp. 1-10, April .

13-Swanson, Matthew A. ( 2018 ) : EMPLOYEE PERCEPTIONS OF SUCCESSION PLANNING WITHIN HIGHER EDUCATION A QUALITATIVE CASE STUDY, Doctoral Study Submitted in Partial Fulfillment of the Requirements for the Degree of Doctor of Business Administration, Liberty University, School of Business .

14-Yadav, S. S., \& Shankar, R. ( 2017 ) : Succession planning : some lessons . Journal of Advances in Management Research, 14(4), doi: 10.1108/JAMR-07-2017-0081 .

15-Ismail, Aziah and Abdullah, Abdul Ghani Kanesan (2011) : Human capital development in Malasian public universities, Current research journal of social sciences, Vol 3 No 5 , pp389-398 .

16- Umans , Ine \& Nadina Lybaert \& Tensie Steijvers \& Wim Voordeckers (2018) : The impact of succession intentions (succession) across generations on success, journal of family business strategy , Hasselt University, RCEF, Agoralaan, 3590 Diepenbeek, Belgium, University of Antwerp, Prinsstraat 13, 2000 Antwerp, Belgium . 